\title{
Growth and Essential Oil Production of Aloysia citiodora L. Grown in Greenhouse Using Soil and Floating System
}

\author{
${ }^{1}$ F. Azarmi, ${ }^{2} \mathrm{H}$. Nazemieh and ${ }^{1}$ M.R. Dadpour \\ ${ }^{1}$ Department of Horticulture, ${ }^{2}$ Department of Medicine, \\ University of Tabriz, P.O. Box 51664, Tabriz, Iran
}

\begin{abstract}
The experiment was conducted in a research greenhouse using soil and floating as a soilless system. Essential oils of Aloysia citriodora L. leaves produced in these systems were extracted and their percent (based on dry weight), yield (per plant) and composition were determined. The number of leaves, leaf area and fresh and dry weight of plants were also measured. For all vegetative parameters, there was a significant difference between two growing systems and plants grown in floating system showed drastic increase compared with soil cultured ones. Growing plants in the soil had a result as $90 \%$ reduction in leaf area compared with floating system. Lemon verbena plants oil production was same in two growing systems while because of more expansion of leave and increased biomass in floating system, the yield of essential oil was higher than those of soil. The major components of essential oil was geranial, neral, $\alpha$-curcumene, D-limonen, geraniol and nerol, although the relative percent of each component were different in tow growing systems. Concentration of geranial $(36.32 \%$ of total oil) and neral $(27 / 88 \%$ of total) was higher in the soil while growing plants in the planting system resulted in more D-limonene, geraniol, nerol and $\alpha$-curcumene. According to the results, floating system can be defined as an efficient method for obtaining high productivity and more extraction of volatile oil in Aloysia citriodora L. plant.
\end{abstract}

Key words: Medicinal herbs, soil, floating, Aloysia citriodora, essential oil, Iran

\section{INTRODUCTION}

Medicinal herbs have always been the subject of interest in all over the world. These plants are cultivated and processed for using of their bioactive substances which are known as secondary metabolites. Since the accumulation of these materials are affected by environmental factors so the proper management of growing environment can result in more productivity and bioactive substances consistency of medicinal and aromatic plants (Charles et al., 1993). Production of medicinal herbs in controlled environment specially in hydroponic systems can led to high quality materials, free from weeds, pathogens and soil or environmental contamination particularly in root medicinal herbs (Dorais et al., 2001; Pagliarulo and Hayden, 2000).

Hydroponic as the method of production plants without soil has long been the technique for commercial production of many plants in most parts of the world. This system is an efficient system for intensive production of plants specially in dry lands and countries with water sources shortage. Production of different plants under hydroponic condition has been investigated and this system has been employed for production of vegetables and flowers in last few decades (Schwarz, 1995).
Soilless production of medicinal herbs is a new trend in agricultural system specially in intensive and organic agriculture (Hassanpouraghdam et al., 2008). Hydroponic systems can provide a unique environment for plants by more aeration and water availability in the root zoon. High quality and more biomass production of medicinal and aromatic plants have been proved in many researches (Dorais et al., 2001; Hyden, 2006; Leonhart et al., 2002; Mairapetyan, 1999; Pagliarulo and Hayden, 2000). All these advantages can be employed by shifting from labor consuming, expensive traditional culture of medicinal herbs to industrial production in open air or greenhouse hydroponic systems (Mairapetyan, 1999).

Lemon verbena is a perennial aromatic plant which grows to $3 \mathrm{~m}$ and is characterized by presence of fragrant, lemon scented narrow leaves. Due to antispasmodic, antipyretic, carminative, sedative and stomachic effects, this plant has been used as a medicinal plant for centuries. The leaves and flowering topes are used in tea and beverage flavor. Its fragrant is used in perfumery (Simon et al., 1984). Extracted essential oil constituents are a little varied in different studies. However, the major part of volatile oil is consisted of granial, neral, limonene and 1,8 sineol (Bellakhtar et al., 1993; Montes et al., 1973).

Corresponding Author: F. Azarmi, Department of Horticulture, University of Tabriz, P.O. Box 51664, Tabriz, Iran 
The aim of this study was to compare the growth and essential oil yield and composition of Aloysia citriodora L. in two different culture systems and suggest the more efficient system to reach high yield and more productivity.

\section{MATERIALS AND METHODS}

The experiment was conducted at hydroponic greenhouse of Horticultural Department, University of Tabriz. Aloysia citriodora L. cuttings were rooted in greenhouse and after for weeks, 6 rooted plants were transplanted to production systems including floating and soil. Each production system was a box frame covered with a thick polystyrene layer. Nutrient solution aerated through a compressor pump was used to fill the floating boxes and 6 holes on the surface of each box were used to hold the plants which their roots were floated in the solution. For soil treatment, boxes were filled with the garden soil. These boxes were randomly placed in greenhouse where the temperature was set $28 \pm 3$ and $20 \pm 3$ at the day and night, respectively and was under natural light. Nutrient solution was adapted from Hogland and Arnon (1950) and was adjusted twice a day. The $\mathrm{pH}$ and Ec of nutrient solution were adjusted to 6-6.5 and 2-2.5 dS $\mathrm{m}^{-1}$ using $\mathrm{H}_{2} \mathrm{SO}_{4}$ or $\mathrm{KOH}$ and water, respectively. Treatments were arranged in the completely randomized design with four replicates.

Plants were harvested after 5 months at their flowering time in order to study their growth parameters and essential oil production. Leaves fresh weight was measured immediately after harvesting and then samples dried for $24 \mathrm{~h}$ at $80^{\circ} \mathrm{C}$ in a air forced oven to measure dry weight. Leaf area was determined after harvesting by a leaf area meter (LI-Cor, Model Li-1300, Lincoln, USA). Chlorophyll index was measured with a spad-502 leaf chlorophyll meter (Minlta, Osaka, Japan) in central leaves of plants.

After drying plants at room temperature, essential oil was extracted using hydrodistillation. Analysis of volatile compound was done by GC-MS (Schimmadzu GCMSQP5050a gas chromatograph mass spectrometer), DB-5 capillary column.

Analysis of data was down using generalized linear model in the SAS program. Difference between means was tested by LSD at $\mathrm{p} \leq 0.05$.

\section{RESULTS AND DISCUSSION}

For vegetative parameters including fresh and dry weight of leaves, leaf number and leaf area of plants grown in floating system showed significantly higher value compared with soil grown ones (Table 1). Leaf fresh weight was 250.3 and $18.1 \mathrm{~g}$ in floating and soil systems, respectively. According to the results both leaf area and leaf fresh weight reduced $>90 \%$ in plants produced in soil plants grown in planting system had more chlorophyll level than floating system grown ones.

The essential oil percent (based on dry weight) and yield (per plant) are shown in Table 1. No significant difference was observed in essential oil percent of two systems while the oil yield had significant difference in two system owing to the different biomass production. Plants grown in floating system has more essential oil yield as a result of more biomass production. The oil yield in soil grown plants showed a reduction by $90 \%$ compared with plants grown in floating. Major constituents of essential oil were geranial, neral, D-limonene and $\alpha$-curcumene. Relative proportion of these components in oil varied in two different systems. In soil grown plants neral ( $36.32 \%$ of total oil) and geranial ( $27.88 \%$ of total oil) had higher percent while $\alpha$-curcumene and d-limonene accumulation in plants grown in soil was more than plants grown in soil (Table 2).

Hydroponic cultivation can be employed as a great tool to study effect of environmental factors on the productivity and quality of medicinal herbs. This technique provides an opportunity to evaluate the root zoon parameters affecting the growth and raw material production of these plants. Higher biomass production of plants in hydroponic relative to soil has been reported by other researchers.

Boyle et al. (1991) described that soil grown rosemary plants had lower stem and root dry weight compared with hydroponically grown ones. Aerial part dry weight of Stellaria medica, Artemisia vulgaris and Inula helenium was 1.9, 3.22 and 12.7 times, respectively, higher in the floating rafts system compared with field grown plants (Dorais et al., 2001).

Expansion of leaf area is one of the most important indexes to estimate the vegetative growth of plants. Increased leaf area is a sign of appropriate growth condition for plants (Cowling and Field, 2003). High biomass production of plants in floating system as

Table 1: Characteristics of Alooysia citriodora plants grown in soil and floating sy stems

\begin{tabular}{llccccc}
\hline Production system & Leaf No. & Leaf fwt. $(\mathrm{g})$ & Leaf dwt $(\mathrm{g})$ & Chlorophyll index & Leaf area (cm $\left.{ }^{2}\right)$ Oil percent (mL/100 g DW) & Oil yield (per plant) \\
\hline Floating & 1290.0 & 250.3 & 58.0 & 33.00 & 12394 & 0.710 \\
Soil & 185.0 & 18.1 & 4.9 & 39.43 & 1233 & 0.82 \\
Significance & 0.0001 & 0.0001 & 0.0001 & 00.05 & 0.0001 & 0.060 \\
\hline
\end{tabular}


Table 2: Percent of essential oil components produced in tow growing systems

\begin{tabular}{|c|c|c|}
\hline \multirow[b]{2}{*}{ Components } & \multicolumn{2}{|c|}{ Total oil (\%) } \\
\hline & Floating & Soil \\
\hline Geranial & 22.98 & 36.32 \\
\hline Neral & 15.98 & 27.88 \\
\hline D- limonene & 6.84 & 3.06 \\
\hline Geraniol & 4.43 & 2.25 \\
\hline Nerol & 2.95 & 1.64 \\
\hline$\alpha$-curcumene & 7.01 & 5.98 \\
\hline Eucalyptol & 3.66 & 2.81 \\
\hline 6- Methyl-5-Hepten- 2-on & 4.02 & 1.35 \\
\hline 1 -octen-3-ol & 1.01 & 0.03 \\
\hline Germacrene -D & 2.20 & 0.26 \\
\hline$\alpha$-Terpineol & 1.84 & 1.36 \\
\hline Nerolidol & 1.75 & 1.31 \\
\hline Caryophyllen oxide & 2.74 & 2.87 \\
\hline Gamma elemen & 1.25 & - \\
\hline$\beta$-Caryophylen & 4.94 & 2.28 \\
\hline Sabinen & 0.55 & 0.34 \\
\hline Alloaromadendrene & 0.48 & 0.46 \\
\hline Trans- $\beta$-ocimene & 0.69 & - \\
\hline Linalol & 0.53 & - \\
\hline$\alpha$-Copaen & 0.76 & 0.43 \\
\hline (-) Spatholenol & 5.60 & 3.76 \\
\hline Geraniol formate & - & 0.26 \\
\hline Delta cadinol & - & 0.75 \\
\hline Citronellal & - & 0.47 \\
\hline Cironellol & - & 0.35 \\
\hline Geranyl acetate & - & 1.45 \\
\hline
\end{tabular}

compared with soil was due to increased leaf area as a photosynthetic unit. Expansion of leaves led to increase photosynthetic capacity of plant and subsequently increase in assimilation and more dry matter accumulation. Providing the highest aeration and balanced distribution of nutrients at all plant growing period is needed to achieve high yields.

The root environment of hydroponic plants is abundantly provided with water, nutrients and air and corresponding increase of the metabolic and absorbing activity of roots and subsequent increase in biological activity in aerial part. This is a long with some physiological and biochemical changes such as increase of photosynthetic potential, chlorophyll and essential oil content and early development of maximal assimilation surface (Mairapetyan, 1999; Taiz and Zeiger, 2002).

This experiment finding indicated that floating system may be an efficient system for growing of Aloysia citriodora results which are accordant with other studies. Mairapetian evaluated growing of some aromatic plants in hydroponic system and showed hydrponically grown aromatic plants have higher productivity, in addition to accumulate 3-6 times more essential oil compared with field grown ones (Mairapetyan, 1999). Pagliarulo assessed some root medicinal herbs under hydroponic system. Plants produced in this study had better roots and more yields compared with conventional produced ones (Pagliarulo and Hayden, 2000).
Providing an optimum growth condition in root zoon including adequate aeration, nutrient adjustment and water availability in addition to multiple harvest and more plants density can be the effective factors on high productivity in hydroponic systems.

Results showed changing in essential oil yield and characteristics as it has been illustrated by other study that growing condition can affect the yield and alter active substances in medicinal herbs (Charles et al., 1993). Accumulation of secondary metabolites can be changed by different environmental factors. Thus, different condition around the zoon in soil and floating systems can be a main reason for dramatic productivity difference with these two growing media.

Although, concentration of essential oil is same in tow growing media, however more production of leaf weight can be a reason of drastic difference in total oil production in this system. However, results implied that more and superior production of Aloysia citriodora L. plants is possible in floating production system.

\section{CONCLUSION}

Floating production system can be suggested as an appropriate technique for lemon verbena plants considering the drastic increase in essential oil yield compared with soil production. High density cultivation, multiple harvest and off-season production of plants can significantly increase yields compared with conventional production. In addition, elimination of some soil problems such as soil born disease, weeds and no need to loosening or herbicide application should also be considered. In general, floating system can be recommended as an efficient system for production of Aloysia citriodora L. plants and may some other leaf aromatic plants. Some additional cares can be used to obtain more productivity and even change the relative proportion of components.

\section{REFERENCES}

Bellakhtar, A., A. Idrissi, S. Canigueral, J. Iglesias and R. Vial, 1993. Analysis of the essential oil of the odorant vevein (Lippia citriodora). Plant Med. Phytother, 26: 269-273.

Boyle, T.H., L.E. Craker and J.E. Andsimon, 1991 . Growing medium and fertilization regim influence growth and essential oil content of rosmary. J. Hort Sci., 26: 33-34.

Charles, D.J., J.E. Simon, C.C. Shock, E.B.G. Feibert and R.M. Smith, 1993. Effect of Water Stress and PostHarvest Handling on Artemisinin Content in the Leaves of Artemisia annua L. In: New Crops, Janick, J. and J.E. Simon (Eds.). Wiley, New York, pp: 628-631. 
Cowling, S.A. and Field, C.B., 2003. Environmental control of leaf areaproduction implication for vegetation and land-surface modeling. Global Biochem. Cycles, 17: 1007-1014.

Dorais, M., A.P.P. Papadopulos, X. Luo, S. Leonart, A. Goosselin, K. Pedneault, P. Angers and L. gaudreau, 2001. Soilles greenhouse production of medicinal plants in north eastern Canada. Acta Hort., 554: 186-189.

Hassanpouraghdam, M.B., S.J. Tabatabaie, H. Nazemiyeh, L. Vojodi and M.A. Aazami, 2008. Essential oil composition of hydroponically grown Chrysanthemum balsamita L. J. Essent. Oil Bear. Plants, 11: 649-654.

Hogland, D.R. and D.S. Arnon, 1950. The waterculture method for growing plants without soil. Calif. Agric. Exp. Stat. Circ., 374: 1-32.

Hyden, A.L., 2006. Aeroponic system for medicinal herbs, rhizomes and root crops. Hort Sci., 41 : 536-538.

Leonhart, S., K. Pedneault, A. Gosselin, P. Angers, A.P. Papadopoulos and M. Dorais, 2002. Diversification of greenhouse crop production under supplemental lighting by the use of new cultures with high economic potential. Acta Hort. (ISHS), 580: 249-254.
Mairapetyan, S.K., 1999. Aromatic plant culture in openair hydroponics. Acta Hort. (ISHS), 502: 33-42.

Montes, M., L. Valenzuela, T. Wilcomirsky and M. Arrive, 1973. Composition of essential oil from Alloysia triphylla (Cedron). Plant Med., 23: 119-124.

Pagliarulo, C.L. and A.L. Hayden, 2000. Potential for greenhouse aeroponic cultivation of medicinal root crops. Paper No. P-125933-10-01. Controlled Environment Agricultural Center, College of Agriculture and Life Sciences, The University of Arizona.

Schwarz, M., 1995. Soilless Culture Management. Springer-Verlag, Berlin, Heidelberg, Germany.

Simon, J.E., A.F. Chadwick and L.E. Craker, 1984. Herbs: An Indexed Bibliography 1971-1980 the Scientific Literature on Selected Herbs and Aromatic and Medicinal Plants of the Temperate Zone. Archon Books, Hamden, CT., ISBN-13: 978-0208019905, Pages: 770 .

Taiz, L. and E. Zeiger, 2002. Plant Physiology. Sinaur associate, Inc. Publisher, Sunderland, USA. 